\title{
Sustainability of water uses in managed hydrosystems: human- and climate-induced changes for the mid-21st century
}

\author{
Julie Fabre $^{1}$, Denis Ruelland ${ }^{1}$, Alain Dezetter ${ }^{2}$, and Benjamin Grouillet ${ }^{1}$ \\ ${ }^{1}$ CNRS, HydroSciences Laboratory, Place Eugene Bataillon, 34095 Montpellier, France \\ ${ }^{2}$ IRD, HydroSciences Laboratory, Place Eugene Bataillon, 34095 Montpellier, France \\ Correspondence to: Julie Fabre (jml.fabre@gmail.com)
}

Received: 30 July 2015 - Published in Hydrol. Earth Syst. Sci. Discuss.: 10 September 2015

Revised: 29 March 2016 - Accepted: 30 May 2016 - Published: 2 August 2016

\begin{abstract}
This paper assesses the sustainability of planned water uses in mesoscale river basins under multiple climate change scenarios, and contributes to determining the possible causes of unsustainability. We propose an assessment grounded in real-world water management issues, with water management scenarios built in collaboration with local water agencies. Furthermore, we present an analysis through indicators that relate to management goals and present the implications of climate uncertainty for our results, furthering the significance of our study for water management. A modeling framework integrating hydro-climatic and human dynamics and accounting for interactions between resource and demand was applied in two basins of different scales and with contrasting water uses: the Herault $\left(2500 \mathrm{~km}^{2}\right.$, France $)$ and the Ebro $\left(85000 \mathrm{~km}^{2}\right.$, Spain) basins. Natural streamflow was evaluated using a conceptual hydrological model. A demanddriven reservoir management model was designed to account for streamflow regulations from the main dams. Human water demand was estimated from time series of demographic, socioeconomic and climatic data. Environmental flows were accounted for by defining streamflow thresholds under which withdrawals were strictly limited. Finally indicators comparing water availability to demand at strategic resource and demand nodes were computed. This framework was applied under different combinations of climatic and water use scenarios for the mid-21st to differentiate the impacts of climateand human-induced changes on streamflow and water balance. Results showed that objective monthly environmental flows would be guaranteed in current climate conditions in both basins, yet in several areas this could imply limiting human water uses more than once every 5 years. The impact of the tested climate projections on both water availability
\end{abstract}

and demand could question the water allocations and environmental requirements currently planned for the coming decades. Water shortages for human use could become more frequent and intense, and the pressure on water resources and aquatic ecosystems could intensify. The causes of unsustainability vary across sub-basins and scenarios, and in most areas results are highly dependent on the climate change scenario.

\section{Introduction}

Water security was defined by the Global Water Partnership (GWP, 2000) by the following:"Water security at any level from the household to the global means that every person has access to enough safe water at affordable cost to lead a clean, healthy and productive life, while ensuring that the natural environment is protected and enhanced". This definition comprises many different concepts, which many authors have tried to define and grasp over the years (Cook and Bakker, 2012). One of the concepts included in the idea of water security is sustainability. A sustainable use of water resources implies being able to satisfy current and future human water demands while preserving functional waterdependent ecosystems (Gleick, 2000). Thus, it implies the ability of users to find a long-term balance between the availability and the use of water resources, a challenge at the heart of integrated water management strategies (Vörösmarty et al., 2012). An imbalance between availability and demand can express itself through the incapacity of water supply to meet demand (be it because of insufficient water availability or excessive water demand), and/or through pressures 
on water-dependent ecosystems due to excessive water consumption by human use. The European Water Framework Directive (WFD) (European Commission, 2000) requires European river basins to reach a sustainable balance between human water use and ecosystem health.

In this setting water sharing plans, when not already enforced, are currently being designed in many river basins. These plans are often focused on the periods compatible with WFD requirements, i.e., the 2015, 2021 or 2027 horizons. However, it is widely recognized that mid-latitude areas could experience increased water stress along the $21 \mathrm{st}$ century, due to climate and socioeconomic changes (Heinrichs et al., 2012; Arnell and Lloyd-Hughes, 2014; Milano et al., 2013b). These projections should encourage decision makers and water managers to look further in the future and perhaps lengthen their planning horizons (Hallegatte, 2009). Moreover, as underlined by Ludwig et al. (2014) the main difference between Integrated Water Resources Management (IWRM) as prescribed in the WFD and climate change adaptation is the focus on current and historic issues of IWRM, compared to the future focus of adaptation.

In this context, projections of water availability and demand at the river basin scale under scenarios of climate and water use changes are essential to develop a long-term perspective in water sharing plans. To date, studies focusing on climate impacts on water management are mostly focused on projections of water resource availability (e.g., Schwank et al., 2014; Bär et al., 2015; Nkomozepi and Chung, 2014; Palazzoli et al., 2015). However achieving a sustainable use of water resources depends not only on hydro-climatic factors (defining the volume of resource) but also on anthropogenic factors such as water demand and water management infrastructures (e.g., storage and transportation capacity), determining the availability of water resources (e.g., Griffin et al., 2013; Menzel and Matovelle, 2010). Also, climate change could have considerable impacts on irrigation requirements (Döll, 2002; Woznicki et al., 2015), which should be accounted for in prospective water balance assessments. Some studies have focused only on water demand (e.g., Grouillet et al., 2015), on fulfilling environmental flow requirements (e.g., Donley et al., 2012), or on the tradeoffs between environmental flow requirements and one type of demand (e.g., Kirby et al., 2014). Wanders and Wada (2015) considered human influence in projections of future drought at a global scale; however, they did not consider possible future changes in water use. A number of studies at the river basin scale assessed the impacts of hydrological changes on the capacity to satisfy current demands (e.g., López-Moreno et al., 2014; Pulido-Velazquez et al., 2011), or future planned demands without considering the possible impact of climate change on agricultural water demand (e.g., Milano et al., 2013a).

Studies that address the issue of water demand satisfaction at the river basin scale are scarce, even more so are studies that account for consumptive use and the influence of hu- man water use on streamflow (one example being the work of Beck and Bernauer (2011). Indeed water sustainability must be assessed through the satisfaction of human water needs, the level of pressure on resources and the respect of environmental instream uses. This implies accounting for and distinguishing water demand (i.e., the amount of water that users would withdraw without restrictions), actual withdrawals and consumptive use, notably in complex river basins with numerous upstream-downstream relationships, reservoirs and water transfers. In a number of existing papers integrating water uses, water management and water availability (e.g., Nam et al., 2015; Shamir et al., 2015), the systems under study were elementary management units, such as individual reservoirs or an aquifer. To our knowledge fewer studies can be found addressing water balance projections in complex, mesoscale river basins, with numerous spatial and temporal interactions between water uses and water availability (e.g., Collet et al., 2013).

Integrated modeling of water balance at the basin scale is an extremely complex task, which necessarily comprises many biases and uncertainties. Questions have been raised on the confidence that can be placed into projections of hydroclimatic changes (Kundzewicz and Stakhiv, 2010; Wilby, 2010). However, if projections of change cannot be considered as predictions and used directly to decide on water allocations or infrastructure dimensioning, models can be used to understand the system under study and to determine the possible causes of change (e.g., Letcher et al., 2007; Pielke, 2009). In this way, Blöschl and Montanari (2010) recommended the use of "simple" models that will help analyze the system, rather than complex models that may never be complete enough to model the system with perfect accuracy. As stressed by Smit and Wandel (2006), "climate conditions and system dynamics that could be problematic are rarely known a priori". Modeling studies can help point out potential problems and discriminate anthropogenic and climatic impacts. While Kirby et al. (2014) found that river flows were more sensitive to the range of climate change projections than to the range of diversion reallocation scenarios considered, other studies found that anthropogenic drivers could have more impact than climatic drivers (e.g., Beck and Bernauer, 2011; Reynard et al., 2014; Vörösmarty et al., 2000).

Uncertainties regarding anthropogenic climate change have been largely discussed in the literature. While some authors issued recommendations on how to improve modeling to better serve decision-making (e.g., Milly et al., 2008) others have stressed the importance of considering climate uncertainties in the decision process, and finding adaptation solutions despite this uncertainty (e.g., Hallegatte, 2009; Patt et al., 2005; Wilby, 2010). Dessai and Hulme (2004) recommended testing the sensitivity of systems to changing probabilities in climate to guide adaptation. Following the framework of robust decision-making (Dessai and Hulme, 2007; Dessai et al., 2009; Wilby and Dessai, 2010), we propose an approach covering a range of possible climate scenarios, 
(a) Herault basin (b) Ebro basin

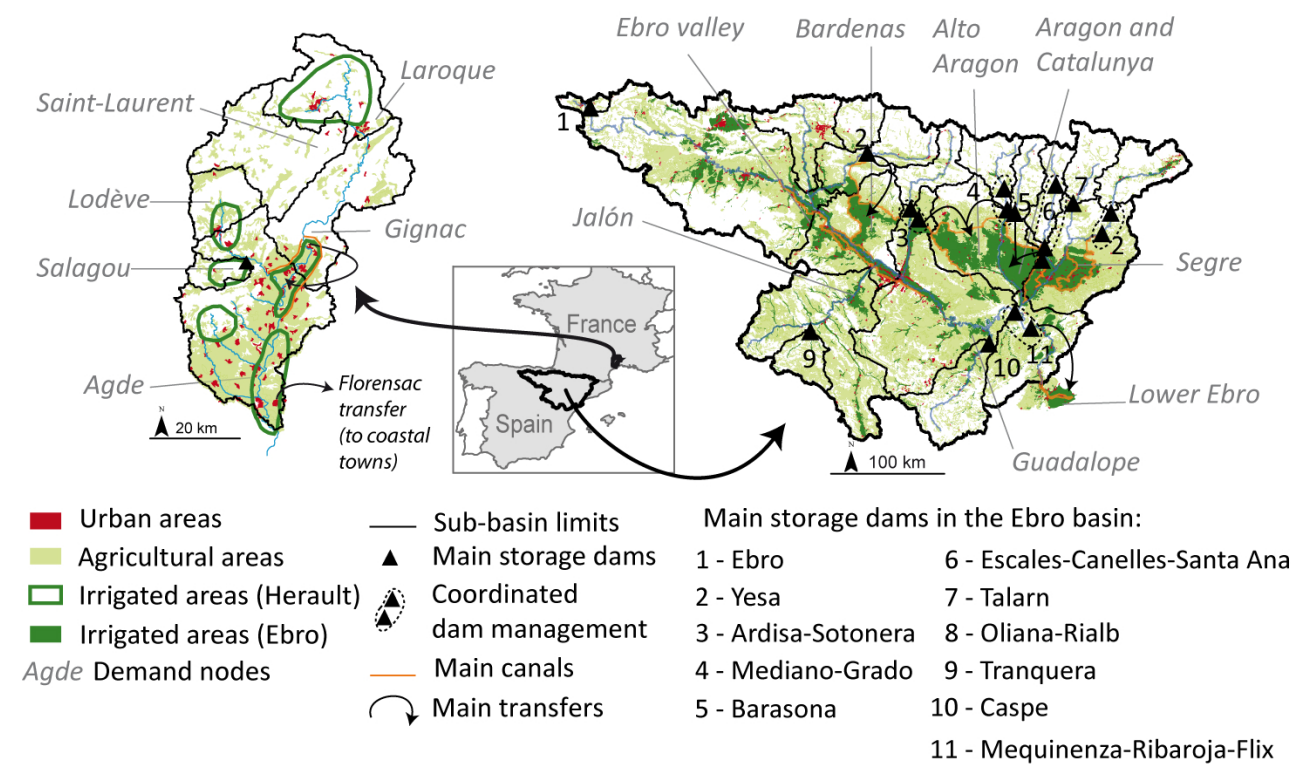

Figure 1. Location, main water uses and water management characteristics of (a) the Herault and (b) the Ebro basins. In the Herault basin, six sub-basins matching six demand nodes were defined. In the Ebro basin, 20 sub-basins were selected for the simulation of water resources and eight demand nodes matching the main irrigation systems were defined. Modified from Fabre et al. (2015a).

given by a selection of global climate models. As underlined by Räisänen (2007), inter-model comparison of climate change projections may be the most pertinent currently available estimate of uncertainty.

The purpose of the present study is thus to assess the sustainability of planned water uses in complex mesoscale river basins under multiple climate change scenarios, and to determine the possible causes of unsustainability. This paper builds on existing work regarding the integrative modeling of the balance between water demand and availability. The development and calibration/validation of the modeling framework used in this paper is exposed in a previously published paper by Fabre et al. (2015a). The present paper also builds on Grouillet et al. (2015), using the same models and water use scenarios to project water demand changes by 2050 under multiple climate change scenarios.

This paper addresses the need for assessments of the sustainability of water use under both climatic and anthropogenic changes at the river basin scale, considering all water uses including environmental requirements and accounting for climate change uncertainty. We propose an assessment grounded in real-world water management issues, with water management scenarios built in collaboration with local water agencies. Furthermore, we present an analysis through indicators that relate to management goals and present the implications of climate uncertainty for our results, furthering the significance of our study for water management. While a previous conference proceedings paper (Fabre et al., 2015b) describes the basics of the method, the present paper contains additional and valuable information on environmental flows, an original analysis of anthropogenic pressure on water resources, a full analysis of the sustainability of water uses and management as they are planned in the two basins, and a complete discussion of the results. Moreover, while the proceedings paper only presented projections of water demand satisfaction for two illustrative demand nodes in each catchment, this paper presents and analyzes results for all demand nodes of the studied basins.

\section{Study areas}

\subsection{Two water management units with contrasting water uses}

This study was conducted in two Mediterranean water management units with contrasting geographical characteristics and water uses, which were presented in Fabre et al. (2015a). The Herault basin $\left(2500 \mathrm{~km}^{2}\right)$, located in the south of France (Fig. 1a), has been part of the territory managed by the Rhône-Méditerranée Corse water agency since 1964, and the Syndicat Mixte du Bassin du Fleuve Herault (SMBFH) was created in the 2000s to ensure more local management and in response to issues that are specific to the Herault basin, including water availability (SMBFH, 2005). The Ebro basin $\left(85000 \mathrm{~km}^{2}\right)$, located in the north of Spain (Fig. 1b), is managed by the Confederación Hidrográfica del Ebro (CHE), which was created in 1926 with a strong emphasis on resource and infrastructure development but now ensures a 
wider role in water management, in line with Integrated Water Resources Management and planning. These two basins already have water sharing issues and could be vulnerable to climate change (Bielsa and Cazcarro, 2015; Collet et al., 2013; Milano et al., 2013a; Vargas-Amelin and Pindado, 2014). Strategies to adapt to future climate change have been designed in both basins (AERMC, 2014; García-Vera, 2013). However, these strategies are lacking projections of the impacts of climate change and sustainability of planned water uses.

Figure 1 shows the main anthropogenic pressures on water resources in the Herault and the Ebro basins. The upstream part of the Herault River basin is characterized by low population density and sparse agricultural areas, whereas the downstream part has a high concentration of urban and agricultural areas (Fig. 1a). The Florensac transfer, which supplies urban water to coastal areas located outside the basin, accounted for one-third of total water demand in 2009. Water demand is highly seasonal, with irrigation demand (mostly for vineyards) and urban demand (increased because of tourism) both peaking between July and August. Of the five dams in the basin with a total storage capacity of $8 \%$ of total runoff (Fabre et al., 2014), the main one is the Salagou dam $\left(102 \mathrm{hm}^{3}\right)$, built in 1968 to supply water for irrigation but currently mostly used for recreational activities on the reservoir lake. The main irrigated areas are concentrated around the Gignac canal which distributes water from the Herault River to a perimeter of nearly 3000 ha of irrigable land. The Ebro is a complex and highly regulated hydrosystem with a total of 234 dams, currently amounting to a storage capacity of $60 \%$ of total runoff (Fabre et al., 2014). Irrigated areas, covering nearly 700000 ha in 2009 , are concentrated in the semi-arid Ebro valley and are supplied by a network of canals linked to large storage dams, most of which collect water from the Pyrenean Mountains. The population density is mostly very low (under 10 inhab. $\mathrm{km}^{-2}$ ) except in a few urbanized areas such as Zaragoza or Pamplona. Urban water demand and water demand for industrial use amounted to comparable volumes in 2009.

\subsection{Conceptual representation of water availability and water demand}

The conceptual representation of water availability and demand presented in Fabre et al. (2015a) was used in each basin: water uses were grouped in water demand nodes each linked to one or more water availability nodes. Water availability nodes were represented either by the surface flow at the outlet of a sub-basin, or by the volumes stored in the main dams. Thus, each basin was divided into sub-basins, accounting for the water supply to one or more demand nodes. The conceptual mapping of both hydrosystems accounted for climatic gradients and water use contrasts (for more details see Collet et al. (2014) and Fabre et al., 2015a). The Herault basin was divided into six sub-basins and the Ebro into 20 (Fig. 1).

In the Herault basin the surface flow at the outlet of each sub-basin was considered to represent water availability for all water uses (inside or outside the basin) supplied by withdrawals inside the sub-basin (Fig. 1a). The southern section of the Herault basin (Agde) has both the highest urban withdrawals and a high level of agricultural water demand. The Gignac canal and its irrigated areas were isolated in the Herault at Gignac sub-basin. Water demand is low and mostly agricultural in the Laroque sub-basin, and minimal in the upstream sub-basins of Saint-Laurent and Lodève.

In the Ebro basin, the links between reservoirs and irrigation systems were accounted for and eight main demand nodes, corresponding to eight main irrigation systems, were defined (Fig. 1b). In cases where the irrigation systems were directly linked to a storage dam, water availability was considered to be the volume stored in the reservoir. In other cases such as the Ebro valley, surface flow is regulated by dams upstream from the water uses, and water availability was considered to be the surface flow at the outlet of the sub-basin in which water is extracted. Note that apart from the eight main demand nodes presented here, a demand node was defined in each of the 20 sub-basins of the Ebro, grouping the water uses not connected to the large irrigation systems. In this paper we will present the balance between water demand and availability only for the eight main demand nodes.

\section{Method}

\subsection{Integrative modeling of the balance between water availability and demand}

\subsubsection{Modeling water availability and demand}

Water availability and demand were modeled following the methods presented in Fabre et al. (2015a) and Grouillet et al. (2015). Natural streamflow was assessed in the six sub-basins in the Herault and the 20 sub-basins in the Ebro using GR4j (Perrin et al., 2003), a conceptual hydrological model run at a daily time step and calibrated/validated at a 10-day time step. The model was calibrated over the period 1981-2009 and validated over the period 1971-1980 (Fabre et al., 2015a). The hydro-climatic data used in the two basins are described in Fabre et al. (2015a). To assess natural runoff in each subbasin, the model was calibrated only against runoff data that were considered to be natural, i.e., not influenced by withdrawals or dam management (see Fabre et al., 2015a).

At each demand node, water demand was defined for human water uses (human water demand) and for environmental requirements (environmental water demand). Three types of human water demand were considered: urban water demand (UWD), agricultural water demand (AWD) and other water demands (OWD). Human water demand was defined 
as the amount of water that users would withdraw without restrictions, i.e., the withdrawals that would enable users to have access to optimal amounts of water considering the efficiency of supply networks and irrigation techniques. UWD referred to water demand for domestic use and for commercial and industrial uses connected to municipal networks. AWD was defined as water demand for irrigation use. Considered negligible in the Herault basin, OWD referred to water demand for industries not connected to municipal networks in the Ebro basin. Water demand for human use was calculated according to anthropogenic drivers (e.g., population and irrigated area dynamics) and climatic drivers (only for agricultural water demand). The data and the models used for the modeling of human water demands can be found in Grouillet et al. (2015) and Fabre et al. (2015a).

Two types of environmental water demand were considered in this study. The first type, called $Q_{\text {MIN }}$, was defined as the streamflow (at a 10-day time step) under which withdrawals for human water use are no longer allowed. This type of minimum flow can also be enforced downstream from a dam or a pumping site, for example, to guarantee availability for other water uses downstream and a minimum flow for the aquatic environment. A second type of environmental flow was considered, in line with planning and water allocations objectives: in water sharing plans, the total volume of water allocated to the different users can be limited to guarantee a minimum monthly average flow, called objective flow or $Q_{\text {OBJ }}$ in this study. This monthly minimum flow is not enforced as such but is used as a planning objective. In the Herault basin for example, water allocations are adjusted to guarantee the respect of this flow at least 8 years out of 10 .

$Q_{\text {MIN }}$ values were defined downstream from storage dams and at specific locations (such as a $30 \mathrm{~m}^{3} \mathrm{~s}^{-1}$ constraint for the Ebro at Zaragoza and a $100 \mathrm{~m}^{3} \mathrm{~s}^{-1}$ constraint for the Ebro at Tortosa; see CHE, 2013), and threshold values were set at the outlet of each sub-basin, under which withdrawals were forbidden. $Q_{\text {OBJ }}$ values were considered in the Herault basin at the outlet of each of the defined sub-basins where the local water agency had defined an objective flow (i.e., at the outlets of the Lodève, Saint-Laurent, Gignac and Agde areas). In the Ebro basin they were considered at the outlet of the defined sub-basins not corresponding to the direct outlet of a dam (for which reserved environmental flows are integrated in the dam management rules). The method used to define these thresholds differed between the two basins, according to the local management rules. In the Herault basin, $Q_{\text {MIN }}$ and $Q_{\text {OBJ }}$ values were defined by local authorities based on variations around $Q_{\mathrm{MNA}}$, (i.e., the minimum monthly flow did not exceeded 1 year out of 5 in past measurements). Thus in the present study the influenced streamflow as simulated by the model in each sub-basin over the period 1981-2009 (see Fabre et al., 2015a) was used to calculate $Q_{\text {MNA5 }}$ and, accordingly, $Q_{\mathrm{MIN}}$ and $Q_{\mathrm{OBJ}}$. For example, the minimum flow defined by local authorities for the Herault at the gauging station of Gignac is $70 \%$ of the $Q_{\text {MNA5 }}$ value observed at this station. Therefore, $Q_{\mathrm{MIN}}$ was then defined as $70 \%$ of the $Q_{\text {MNA5 }}$ as simulated by the model at the gauging station of Gignac over the period 1981-2009. In the Ebro basin $Q_{\text {MIN }}$ (and $Q_{\mathrm{OBJ}}$, considered equal to $Q_{\mathrm{MIN}}$ ) were defined at the outlet of each sub-basin as $10 \%$ of the mean annual natural streamflow (simulated as described in Fabre et al., 2015a) over the period 1981-2009 (or 5\% of mean annual flow if it exceeded $80 \mathrm{~m}^{3} \mathrm{~s}^{-1}$ ).

A demand-driven dam management model adapted from Fujihara et al. (2008) presented in Fabre et al. (2015a) was run to simulate streamflow regulation and storage operations of each dam (the Salagou dam in the Herault basin and 11 major dams in the Ebro basin). The model computes the water balance of the reservoirs at each 10-day time step, accounting for water demand, entering streamflow, evaporation and the initial reservoir level. Considering minimum and target reservoir levels, it calculates the reservoir level, the volume of water released in associated canals (if applicable) and in the river downstream from the dam during each 10-day time step.

\subsubsection{Comparing water availability and demand and simulating influenced streamflow}

Water availability and demand were compared at each water demand node, following the method described in Fabre et al. (2015a) but adding environmental flows $Q_{\text {MIN }}$ as the water demand to be satisfied in the first order of priority. The order of priority for water uses is shown in Fig. 2. If water availability was equal to or higher than water demand, then water withdrawals were equal to water demand for all types of human water demand. If water availability was lower than water demand, then restrictions were applied to limit withdrawals for human uses. Restrictions were first applied to AWD, then OWD, then UWD. No restrictions were imposed on industrial and urban demand before agricultural withdrawal restrictions reached $100 \%$ of demand. Water shortage was calculated through the difference between water demand and effective water withdrawal. Only a part of the water withdrawn was considered to be actually used (consumptive use), the remaining part was considered to return to the sub-basin outlet as return flow (see Fabre et al., 2015a). Thus, the modeling chain simulated

- natural water resources and their availability considering water management rules and infrastructures;

- the ability to satisfy water demands throughout the basin;

- the influenced streamflow resulting for hydro-climatic conditions and anthropogenic pressures (water withdrawals, return flows and dam management).

The modeling chain was calibrated over the period 19812009 and validated over the period 1971-1980 at a 10-day 


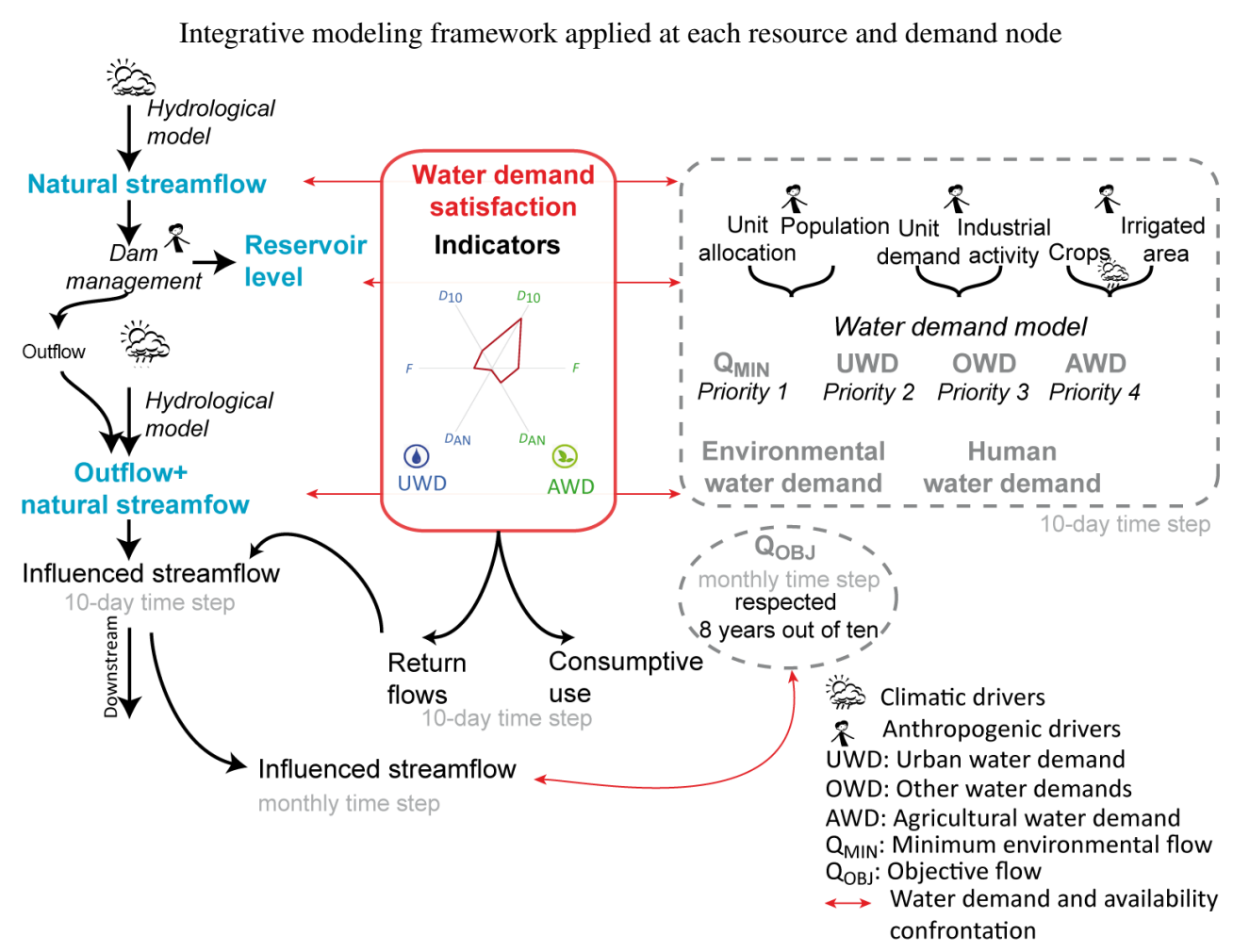

Figure 2. Integrative modeling framework applied at each resource and demand node of the Herault and the Ebro basins. Water demand and natural streamflow were simulated based on climatic and anthropogenic drivers. Anthropogenic influence on streamflow was assessed through the simulation of demand-driven dam management and consumptive use. Water demand satisfaction was assessed by comparing demand to availability.

time step, and simulated water supply capacity and influenced streamflow efficiently in both basins (Fabre et al., 2015a).

\subsection{Climate and water use scenarios for the mid-21st century}

\subsubsection{Climate scenarios}

The climate scenarios used are presented succinctly in Fabre et al. (2015b). Climate scenarios covered a reference period (1976-2005, considered to be representative of current climatic variability) and a future period centered on 2050 (2036-2065). For each basin daily climate forcings over the period 1976 to 2005 were extracted from the $8 \mathrm{~km} \times 8 \mathrm{~km}$ grids presented in Fabre et al. (2015a). For the Herault basin, climatic data came from the SAFRAN (Système d'analyse fournissant des renseignements atmosphériques à la neige) meteorological analysis system (Vidal et al., 2010) and $E_{T_{0}}$ was calculated using the FAO Penman-Monteith formula (Allen et al., 1998). For the Ebro basin, daily temperature and precipitation measurements from 264 and 818 stations, respectively, were interpolated on an $8 \mathrm{~km} \times 8 \mathrm{~km}$ grid (Dezetter et al., 2014; Fabre et al., 2015a). The Hargreaves empirical equation (Hargreaves and Samani, 1985) was used to calculate $E_{T 0}$ at a daily time step.

In order to cover a range of possible climate projections and thus limit over-reliance on a limited number of climate projections (Wilby and Harris, 2006), 18 future climate scenarios were built based on the outputs from nine Global Climate Models (GCMs, see Table 1) from the Coupled Model Intercomparison Project Phase 5 (CMIP5). Using a large set of GCMs is indeed recommended since the dispersion between climate projections stems mainly from the climate models (Arnell et al., 2004; Dessai and Hulme, 2007). The mid-21st century (2036-2065) was chosen for projections through a compromise between local projections of water uses (generally for 2030) and the necessity to use climate projections in which a signal of climate change could be distinguished from climatic variability.

All simulations of climate change were based on the historical Representative Concentration Pathway (RCP) over the reference period (1976-2005) and the RCPs 4.5 and 8.5 over the future period (2036-2065). The outputs from the nine GCMs were extracted from the IPCC Data Distribution Center. Climate change scenarios were then generated using a change factor method (e.g., Déqué, 2007; Milano et al., 2013b; Ruelland et al., 2012). For each GCM grid cell, the 
Table 1. Selected GCMs from the IPCC Data Distribution Center: model name, modeling center, atmospheric resolution and main reference. Source: IPCC (2013)

\begin{tabular}{|c|c|c|c|}
\hline Model name & Modeling center (country) & Atmospheric resolution & Reference \\
\hline CanESM2 & $\begin{array}{l}\text { Canadian Centre for Climate Modeling and } \\
\text { Analysis (Canada) }\end{array}$ & $1.875^{\circ} \times 1.875^{\circ}$ & von Salzen et al. (2013) \\
\hline CNRM-CM5 & $\begin{array}{l}\text { Centre National de Recherches } \\
\text { Météorologiques/Centre Européen de } \\
\text { Recherche et Formation Avancée en Calcul } \\
\text { Scientifique (France) }\end{array}$ & $1.4^{\circ} \times 1.4^{\circ}$ & Voldoire et al. (2013) \\
\hline CSIRO-MK3.6.0 & $\begin{array}{l}\text { Commonwealth Scientific and Industrial } \\
\text { Research Organization in collaboration } \\
\text { with Queensland Climate Change Centre of } \\
\text { Excellence (Australia) }\end{array}$ & $1.875^{\circ} \times 1.875^{\circ}$ & Rotstayn et al. (2012) \\
\hline GFDL-ESM2G & $\begin{array}{l}\text { NOAA Geophysical Fluid Dynamics } \\
\text { Laboratory (USA) }\end{array}$ & $2.5^{\circ} \times 2^{\circ}$ & Dunne et al. (2012) \\
\hline HADGEM2-CC & Met Office Hadley Centre (UK) & $1.875^{\circ} \times 1.25^{\circ}$ & $\begin{array}{l}\text { Collins et al. (2011), } \\
\text { Martin et al. (2011) }\end{array}$ \\
\hline HADGEM2-ES & Met Office Hadley Centre (UK) & $1.875^{\circ} \times 1.25^{\circ}$ & $\begin{array}{l}\text { Collins et al. (2011), } \\
\text { Martin et al. (2011) }\end{array}$ \\
\hline IPSL-CM5A-MR & Institut Pierre-Simon Laplace (France) & $1.25^{\circ} \times 1.25^{\circ}$ & Dufresne et al. (2013) \\
\hline MIROC5 & $\begin{array}{l}\text { Atmosphere and Ocean Research Institute, } \\
\text { National Institute for Environmental } \\
\text { Studies and Japan Agency for Marine- } \\
\text { Earth Science and Technology (Japan) }\end{array}$ & $1.40625^{\circ} \times 1.40625^{\circ}$ & Watanabe et al. (2010) \\
\hline MPIM & $\begin{array}{l}\text { Max Planck Institute for Meteorology } \\
\text { (Germany) }\end{array}$ & $1.8^{\circ} \times 1.875$ & Stevens et al. (2013) \\
\hline
\end{tabular}

monthly variations obtained between the reference and future climatic simulations were applied to the observed series of $T$ and $P$ (over the reference period 1971-2005) of the cells of the $8 \mathrm{~km} \times 8 \mathrm{~km}$ grids, whose center was included within the said GCM grid cell. $E_{T 0}$ was then calculated in each climate change scenario, using the FAO Penman-Monteith formula in the Herault basin and the Hargreaves empirical equation in the Ebro basin. The climate data other than temperature that are required in the Penman-Monteith formula (e.g., wind speed, net radiation) were considered unchanged in the climate scenarios: the values from SAFRAN over 1976-2005 were used in all climate scenarios for 2036-2065.

\subsubsection{Water use scenarios}

Water uses were considered through two scenarios in each basin: current water uses and a trend scenario for 2050. Current water uses were defined with the population, irrigated areas, network efficiency, touristic activity and unit allocations of the 2000s. Current water uses and the trend scenarios used in this study are presented in Grouillet et al. (2015). However, while simulations of water demand changes by 2050 were initially computed for 6 sub-basins of the Herault basin and 20 sub-basins of the Ebro basin, they were aggregated in the present study at the scale of the main demand nodes ( 6 nodes in the Herault basin and 8 nodes in the Ebro basin, see Fig. 4), which made it possible to analyze the balance between water availability and demand.

As part of planning for the respect of the European Water Framework Directive, local agencies make projections of changes in water uses by 2027. The trend scenario was built based on these projections (e.g., for irrigated areas and irrigation efficiency) and the continuation of the trends in these projections (e.g., for population growth) until 2050. The changes applied to the main drivers of water demand between the current and the trend water use scenarios were distributed spatially between the demand nodes. Population projections were based on the median scenarios of the national statistic institutes (Institut national de la statistique et des études économiques (INSEE) in France, Instituto Nacional de Estadística (INE) in Spain). Unit allocations for urban water demand were taken from a study of water uses in the region for the Herault and from projections by the CHE in the Ebro. In the Herault basin, Rinaudo (2011) suggested a $12 \%$ decrease in domestic unit consumption between the 2000s and 2050, linked with forecasted behavioral changes and improved control of water consumption by household appliances. However, projections also suggest an increased connection rate of small industries, parks and gardens and commercial water uses to potable water networks, inducing a total increase of urban unit allocation by $21 \%$. The efficiency of the potable water network was considered to vary in the Herault according to local objectives in line with a national 
policy to reduce losses, and remained constant in the Ebro, where networks are considered already efficient. A prospective study was led in the Herault basin within the water sharing plan, in which an inventory of local irrigation projects was made (regardless of available resources). These projections were used in the trend scenario. In the Ebro basin, irrigated areas were considered to reach their maximum extent defined by the CHE (2013). Changes in population (permanent and touristic) and unit urban water consumption were applied uniformly to all demand nodes, whereas changes in network and irrigation efficiency, irrigated areas and industrial activity were different for each demand node. More details on the trend water use scenarios for 2050 can be found in Grouillet et al. (2015).

\subsection{Analysis of the relative impact of climate and water use scenarios}

\subsubsection{Combinations of climate and water use scenarios}

The modeling framework was applied under four combinations of climate and water use scenarios to differentiate the impacts of climatic and anthropogenic changes on water supply capacity. These combinations and their corresponding objectives are presented in Table 2.

Natural streamflow in the reference climate was simulated by running the hydrological model with climate input data from 1976 to 2005 . For the simulation of natural streamflow over the period 2036-2065, the hydrological model was run with climate input data from each of the 18 climate scenarios described in Sect. 3.2.1. The parameters obtained by calibration over 1981-2009 were kept identical in all simulations.

Water demand for human water uses was calculated at each demand node for current water uses and for future water uses, both under past and future climate conditions for irrigation water demand. The thresholds $Q_{\mathrm{MIN}}$ and $Q_{\mathrm{OBJ}}$ for environmental water demand were kept unchanged in all scenarios.

The dam management model was run with the hydroclimatic and water demand inputs corresponding to each combination of scenarios. Future water use scenarios also include changes in dam management such as the doubling of the Yesa dam's storage capacity, a project currently under way in the Ebro basin. Thus, target reservoir levels were changed accordingly in combinations regarding the trend water use scenario (future uses under past climate and future uses under future climate). Target and minimum levels remained unchanged for the other dams.

\subsubsection{Indicators of water demand satisfaction and anthropogenic pressure on water resources}

As detailed in Sect. 3.1.2, water shortage was calculated at each demand node and for each type of demand, at a 10-day time step. The satisfaction of urban and agricultural water demand was then characterized by three indicators:

- $F$ : frequency of years with at least one significant deficit at a 10-day time step ( $>5 \%$ of UWD or AWD);

- $D_{10}:$ average deficit at a 10 -day time step;

- $D_{\mathrm{AN}}$ : average annual deficit.

These indicators inform us on the frequency and magnitude of water shortages. $D_{10}$ was calculated by averaging the non-null deficits (i.e., water shortage as a percentage of water demand) computed at a 10-day time step over the whole period. Water shortages were summed for each year and the annual deficit was defined as the percentage of total annual demand that could not be satisfied by available resources. $D_{\mathrm{AN}}$ was then calculated by averaging the non-null annual deficits over the whole period. The three indicators were computed separately for UWD and AWD.

For each combination of scenarios the level of anthropogenic pressure on water resources was calculated: the difference between natural and influenced streamflow was calculated at the outlet of each basin at a 10-day time step, and averaged over the 30-year period. The level of anthropogenic pressure was expressed as a percentage of natural streamflow.

Finally, simulated influenced monthly streamflow was compared for each combination of scenarios to the monthly environmental flows $Q_{\text {OBJ }}$ described in Sect. 3.1.1 and the frequency of non-compliance with these monthly environmental flows was calculated.

\section{Results}

\subsection{Hydro-climatic and water demand changes}

\subsubsection{Projections of hydro-climatic changes for the mid-21st century}

Figure 3 shows the changes in the temperature, precipitation and natural discharge projected by the nine GCMs and two RCPs for the period 2036-2065 in comparison to the 19762005 reference period in the Herault and the Ebro basins. Temperature projections show a clear increasing trend, particularly marked in the summer (up to $+4.8^{\circ} \mathrm{C}$ in the Herault basin and $+4.6^{\circ} \mathrm{C}$ in the Ebro basin). Precipitation projections are more uncertain and differ among the 18 scenarios. Annual precipitation changes range from -13 to $+7 \%$ in the Herault and from -15 to $+5 \%$ in the Ebro basin. Nevertheless, spring and summer precipitation are projected to decrease or slightly increase in both basins; in the already dry months of June, July and August all scenarios project a decrease in precipitation.

These climatic scenarios result in changes in simulated natural discharge: while scenarios diverge in fall, winter and spring, all 18 scenarios result in a decrease in summer low 
Table 2. Four combinations of climate and water use scenarios applied in the Herault and the Ebro basins.

\begin{tabular}{|c|c|c|c|}
\hline Combination & Water uses & Climate & Aim of the assessment \\
\hline Current uses under past climate & $2000 \mathrm{~s}$ & 1976-2005 & $\begin{array}{l}\text { Sustainability of current water uses } \\
\text { under reference climate variability }\end{array}$ \\
\hline Current uses under future climate & $2000 \mathrm{~s}$ & $2036-2065$ & $\begin{array}{l}\text { Sustainability of current water uses } \\
\text { under climate change }\end{array}$ \\
\hline Future uses under past climate & $2050 \mathrm{~s}$ & 1976-2005 & $\begin{array}{l}\text { Sustainability of planned water uses } \\
\text { under reference climate variability }\end{array}$ \\
\hline Future uses under future climate & $2050 \mathrm{~s}$ & $2036-2065$ & $\begin{array}{l}\text { Sustainability of planned water uses } \\
\text { under climate change }\end{array}$ \\
\hline
\end{tabular}

(a) Herault
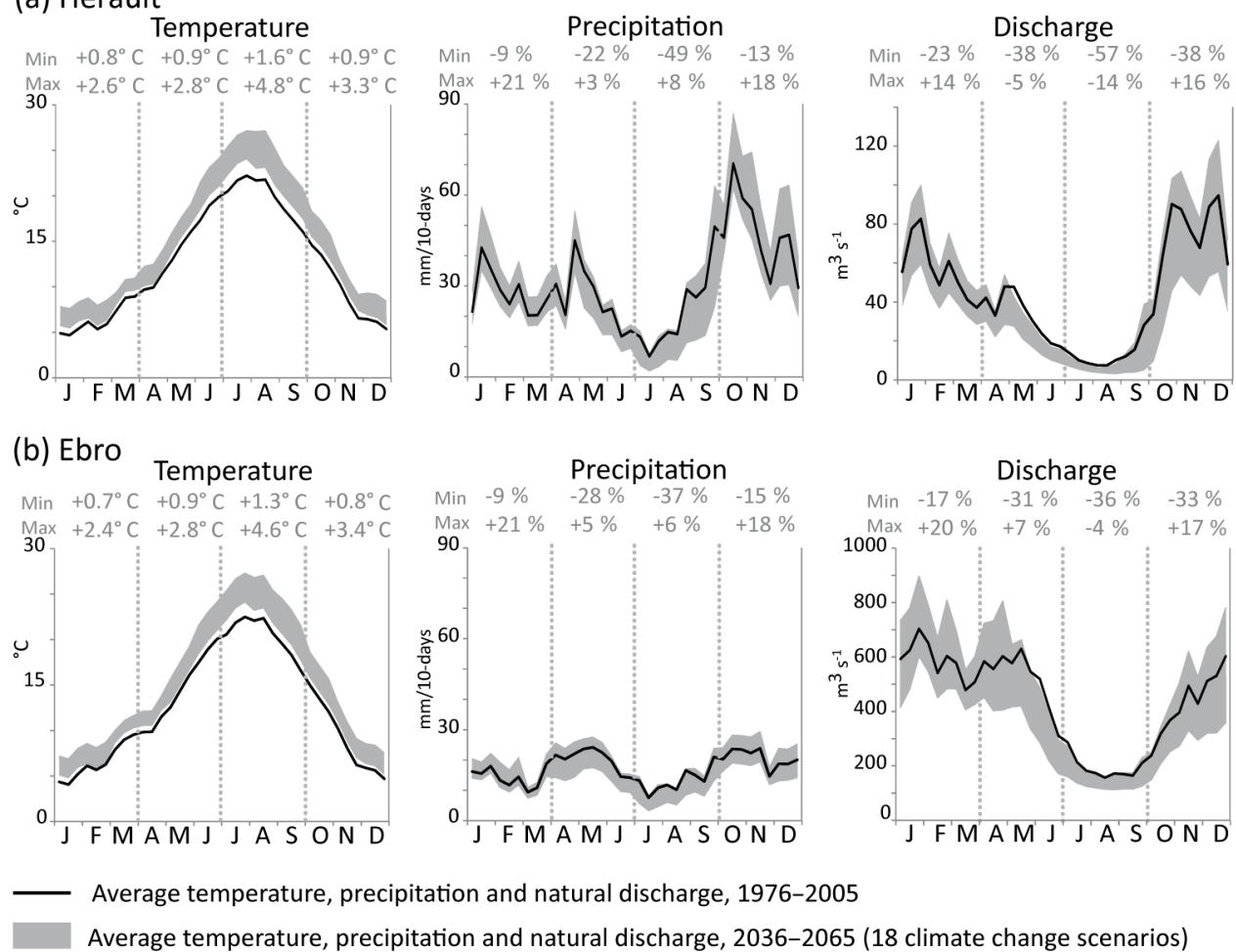

Average temperature, precipitation and natural discharge, 1976-2005

Average temperature, precipitation and natural discharge, 2036-2065 (18 climate change scenarios)

Figure 3. Average temperature, precipitation and natural discharge over the reference period 1976-2005 and under 18 climate change scenarios at the 2050 horizon in (a) the Herault and (b) the Ebro basins. Natural discharge is simulated with the hydrological model over the reference and future period. Modified from Fabre et al. (2015b).

flows, slightly more marked in the Herault $(-14$ to $-57 \%)$ than in the Ebro ( -4 to $-36 \%$ ) basin. In the Ebro basin discharge changes at the beginning of spring (April) are uncertain, with a possible increase in discharge due to increased and earlier snowmelt, while all scenarios lead to a decrease in spring discharge in the Herault basin.

\subsubsection{Water demand changes under water use and climate scenarios}

Simulations of water demand changes by 2050 were initially computed in Grouillet et al. (2015) under the trend water use scenarios and nine climate change scenarios, for six subbasins in the Herault basin and 20 sub-basins in the Ebro basin. Here water demand projections are presented per demand node (which differ from the 20 sub-basins of the Ebro in Grouillet et al., 2015) and for 18 climate change scenarios, showing the dispersion between results for different climate scenarios, adding to the information on average changes presented originally. Thus, the results presented here show the sensitivity of water demand projections to contrasted climate projections.

In the Herault basin projections of water demand for the mid-21st century are contrasted between the upstream and 

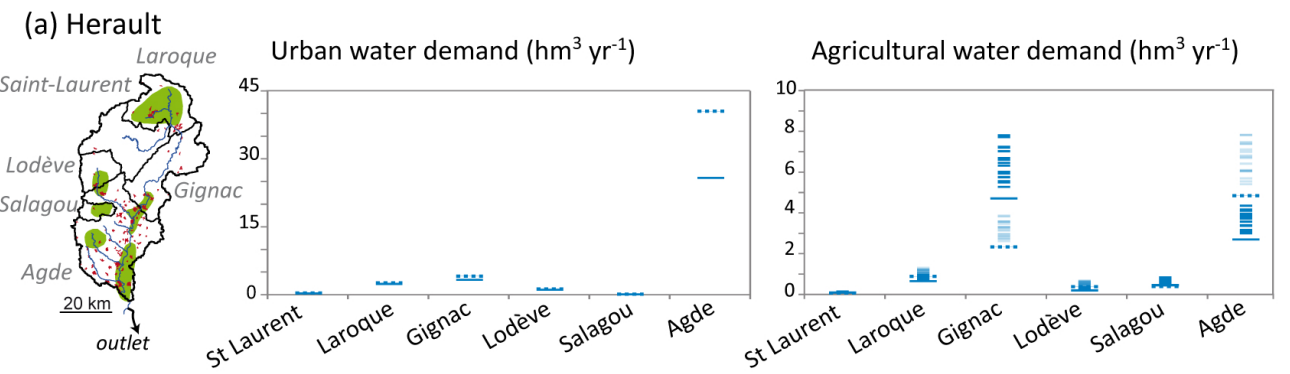

(b) Ebro
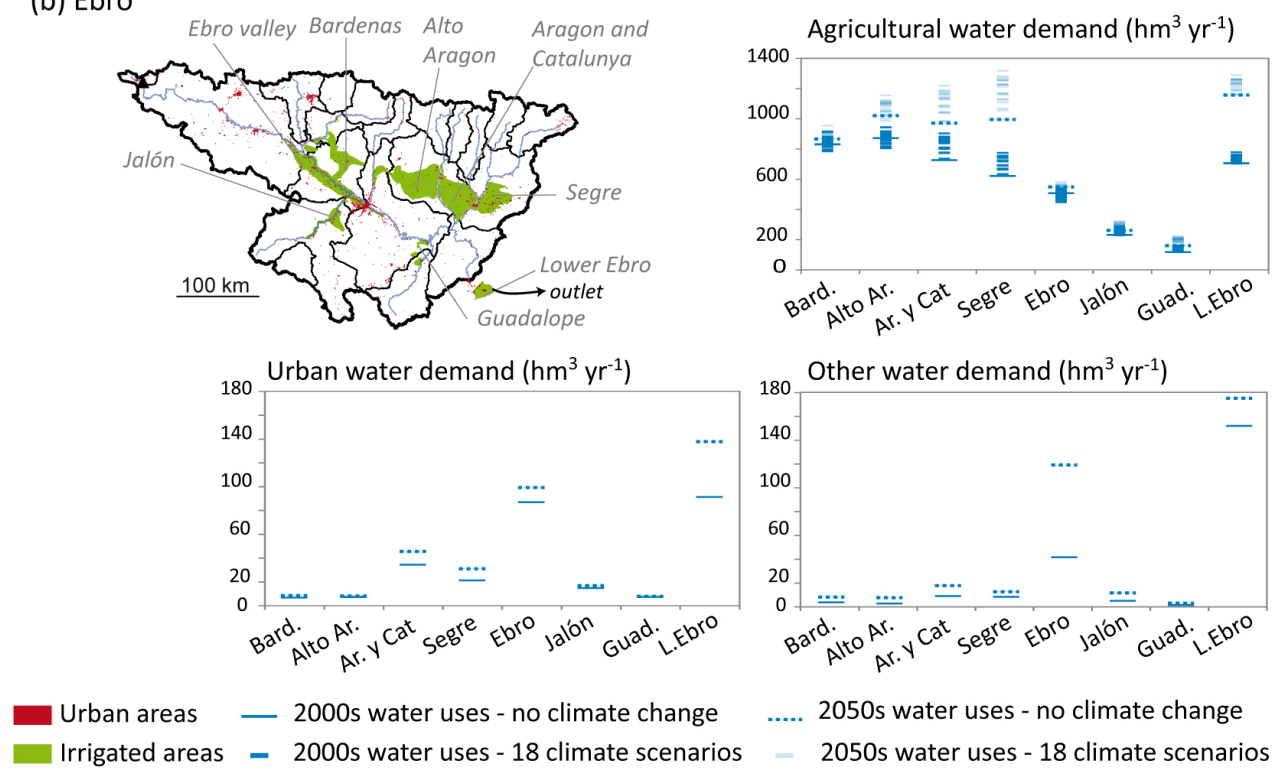

Figure 4. Water demands for human activities in (a) the Herault and (b) the Ebro basins under four combinations of water use and climate scenarios.

downstream sections (see Fig. 4a). Although demand is expected to increase in some upstream sections such as Laroque and Lodève, projected agricultural demand remains low relatively to the downstream sections of Gignac and Agde. Depending on the water use scenario considered, the highest AWD is found in the downstream sections of Gignac or Agde. In the Gignac section the increase in efficiency in the water use trend scenario leads AWD to decrease by $50 \%$ despite a $65 \%$ increase in irrigated areas, whereas AWD in the Agde section doubles in the trend scenario because of a $90 \%$ increase in irrigated areas. In both sections the impact of projected climate change on AWD is comparable to the impact of projected anthropogenic changes (in the most pessimistic climate change scenarios). Note the UWD increase $\left(+57 \%\right.$ or $14.8 \mathrm{hm}^{3}$, of which $10.4 \mathrm{hm}^{3}$ are linked to an increase in demands outside the basin) in the Agde section, which concentrates $83 \%$ of the basin's UWD in the water use trend scenario. In the upstream sections the impacts of projected climate and anthropogenic changes on agricultural water demand are of the same order of magnitude. In the SaintLaurent and Salagou sections, the water use trend scenario causes a slight decrease in AWD $(-15 \%)$; however, chang- ing climate conditions have a dominant impact and cause an increase in AWD (up to +40 and $+57 \%$ in the Saint-Laurent and Salagou sections, respectively). UWD is projected to increase in the upstream sections, from $+11 \%$ in the Laroque section to $+53 \%$ in the Salagou section.

AWD is projected to increase in all sections of the Ebro basin and in all scenarios, except in the Bardenas, Alto Aragon and Ebro Valley irrigated areas where some of the climate change scenarios lead to a decrease in AWD with current water uses. In the water use trend scenario, irrigated areas are projected to increase in all basins, particularly in the Segre and lower Ebro areas. In these areas the impact of the trend scenario is stronger than the impact of some scenarios of climate change (see Fig. 4b). In the Bardenas, Aragon y Catalunya, Jalón and Guadalope areas climate change is projected to have as much or more of an impact on AWD than the changes in water use in the trend scenario. The uncertainty on the impact of climate change on AWD is largest in the Aragon and Catalunya, Segre, Jalón and Guadalope areas; it is lowest in the lower Ebro area. Although AWD stays dominant in all scenarios, UWD and OWD are also projected to increase in all areas in the trend scenario. The highest UWD 
(a) Herault
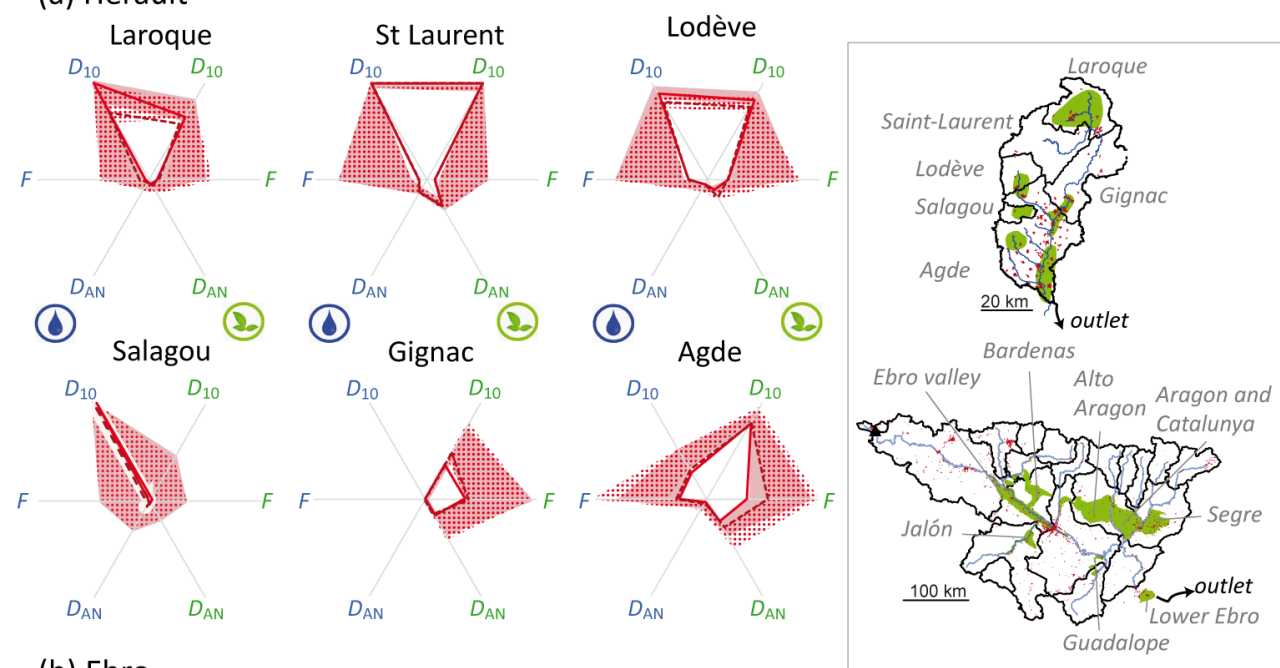

(b) Ebro
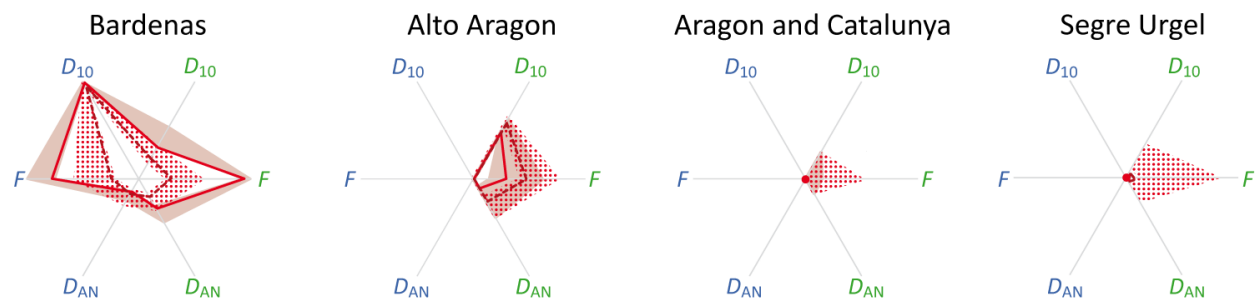

(C)

(C)
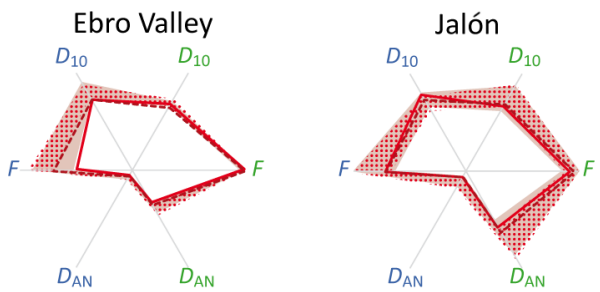

(C)

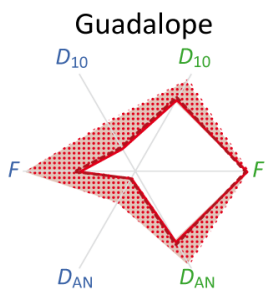

(C)

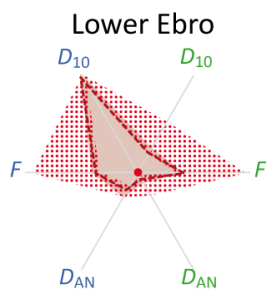

Water demand satisfaction indicators

2000s water uses reference climate

- - 2050s water uses 2000s water uses reference climate

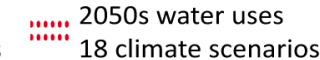

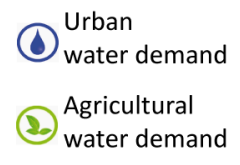

$D_{10}$ : average 10 -day deficit

F: Frequency of years with deficit

$D_{\text {AN }}$ : average annual deficit

Figure 5. Water demand satisfaction indicators for urban and agricultural water demands in (a) the Herault basin and (b) the Ebro basin under four combinations of water use and climate scenarios. Each radar chart presents the results for one demand node. For all three indicators values range from 0 (no deficit) to 1 (maximum frequency or intensity of deficit).

increases are found in the Aragon and Catalunya $(+30 \%)$, Segre $(+45 \%)$ and lower Ebro $(+50 \%)$ areas. OWD is projected to double or more in all sections except the Segre and lower Ebro (from $+100 \%$ in Aragon and Catalunya to $+185 \%$ in the Ebro Valley).

\subsection{Water demand satisfaction under climate and water use scenarios}

\subsubsection{Water demand satisfaction in the Herault basin}

Considering current water uses in the reference climate variability, water shortages appear less than once every 5 years in all sections of the Herault basin except in the Gignac and Agde areas, where agricultural water shortage occurs 2 years out of 5 (Fig. 5a). In the Saint-Laurent and Lodève sections, the average restriction on agricultural water demand at a 10- 


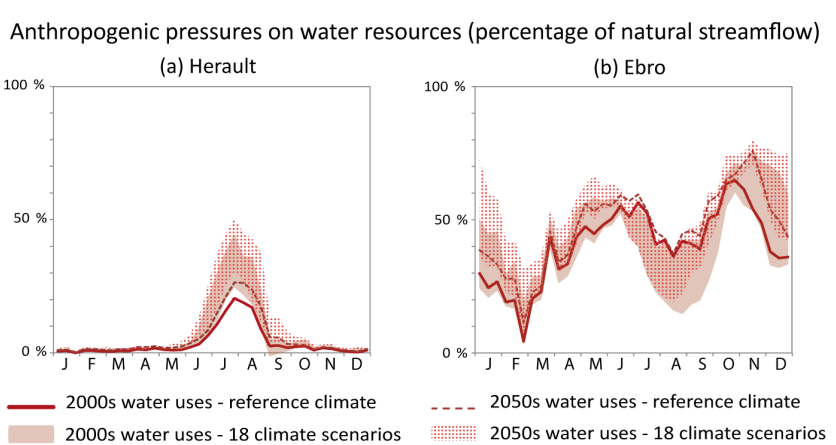

Figure 6. Anthropogenic pressures on water resources under four combinations of climate and water use scenarios in (a) the Herault basin and (b) the Ebro basin. Anthropogenic pressure is computed through the difference between natural and influenced streamflow at the outlet of each basin, expressed as a percentage of natural streamflow.

day time step reaches nearly $100 \%$, while restrictions are less severe in the other sections. The annual deficit is highest in Saint-Laurent and Agde, nearing $20 \%$ of agricultural water demand.

The trend water use scenario in a reference climate only impacts the satisfaction of AWD in the Agde area. Despite a significant decrease in AWD in the Gignac area, the frequency of withdrawal restrictions is not projected to decrease, due to the high UWD increase in the Agde area. Indeed UWD was considered of first priority over AWD and no upstream priority was given to AWD in Gignac over UWD in Agde. Thus, if streamflow was insufficient to meet water demand in the downstream sub-basin, agricultural withdrawals upstream were limited.

Considering current water use in climate change scenarios, water demand and availability become out of balance in all sections of the Herault basin. However, results are highly dependent on the climate scenario, particularly regarding the frequency of water shortages: depending on the climate scenario, the frequency of agricultural water shortages in the Gignac area reaches 3 to 8 years out of 10 . Despite some possible high increases in the frequency of water shortages, the average annual deficits are not affected by climate change except in the Gignac area, where the annual agricultural water deficit reaches $30 \%$ under the most pessimistic climate change scenarios.

Finally, results for planned water uses under climate change scenarios show that projected climate change has a higher impact than the water use trend scenario in all sections of the Herault. In the sections of Gignac and Agde, the water use trend scenario amplifies the impact of the different climate change scenarios.

\subsubsection{Water demand satisfaction in the Ebro basin}

In the combination of current water uses and reference climate variability, results show that the Bardenas, Ebro Valley and right bank systems (Jalón and Guadalope) are out of balance, with agricultural water shortages every year and annual deficits of $30 \%$ in the Ebro Valley and Bardenas, and $60 \%$ and $70 \%$ in the Jalón and Guadalope areas (see figure 5b). Also, shortages at a 10-day time step are higher in the right bank systems. Urban water shortages also appear frequently in these areas.

Combined with current water uses, climate change scenarios induce an increase in the frequency of shortages in the Alto Aragon and lower Ebro areas for AWD, and in the Bardenas, Ebro valley and right bank systems for UWD. Projected climate change also increases the magnitude of annual deficits except in the Ebro Valley and lower Ebro. The impacts are most uncertain in the Alto Aragon and lower Ebro areas. Note that water demand satisfaction in the Segre is not impacted by climate change if no changes in water uses occur. It is also hardly impacted in the Aragon and Catalunya area.

The water use trend scenario under reference climate variability results in a significant improvement of the balance between water demand and availability in the Bardenas system, for both urban and agricultural water uses. The increase of the Yesa dam's storage capacity is projected to lead to a decrease in the frequency of agricultural water shortages, from every year to 3 years out of 10 . In the already out of balance systems of Guadalope, Jalón and the Ebro Valley, and in the balanced systems of Segre and Aragon and Catalunya the water use scenario has little to no impact on water demand satisfaction. Finally, the increase in AWD in the Alto Aragon area and the increase in all types of water demand in the lower Ebro in the trend scenario induces an increase in the frequency of AWD shortage in Alto Aragon and causes AWD and UWD shortages to appear in the lower Ebro.

The combination of the water use trend scenario and climate change scenarios lead to significant water shortages in the entire Ebro basin, with marked differences between the areas. The benefits of the dam enlargement in the Bardenas area are partly offset by climate change in some of the scenarios. Thus, the range of climate change scenarios tested in this study makes the efficiency of this adaptation strategy quite uncertain. In the Ebro valley and the right bank systems, projected climate change causes an increase in the magnitude of water shortages and an increase in the frequency of urban water shortages. However, in these areas the main causes of imbalance seem to reside in the current conditions, water use and climate changes only causing a slight deterioration in already imbalanced systems. In the lower Ebro and Segre areas the combination of projected water use and climate changes lead to frequent agricultural water shortages in both areas (every year in the lower Ebro, 8 years out of 10 in the Segre) and to urban water shortages in the lower Ebro. 
(a) Herault

1- Lodève 2-St-Laurent
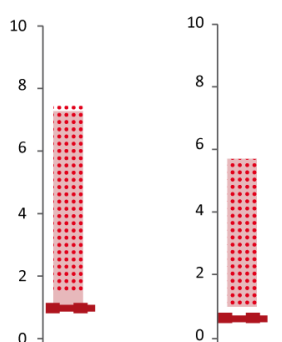
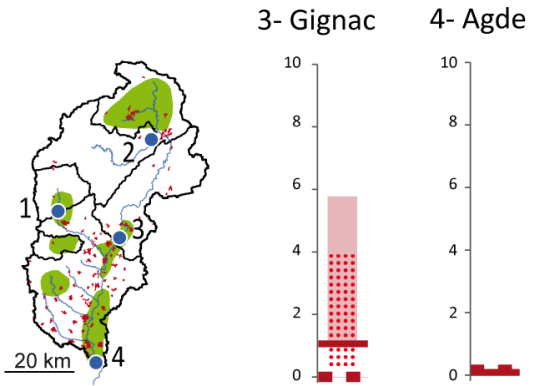

(b) Ebro
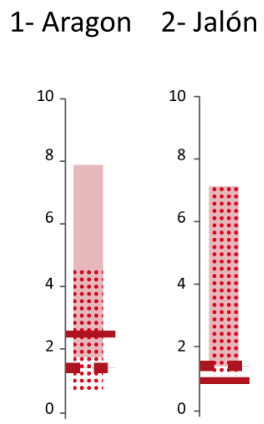

3- Ebro (Zaragoza)

Frequency of non-respect of monthly environmental flows (years out of 10) 2000s water uses reference climate
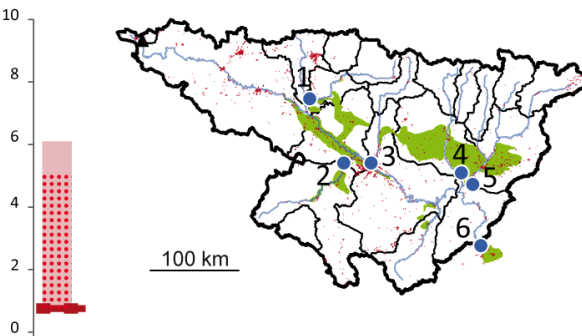

4- Cinca

5- Segre

6- Ebro

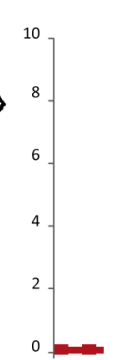

(Tortosa)

18 climate scenarios

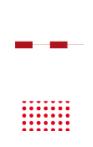

2050s water uses

reference climate

2050s water uses

18 climate scenarios

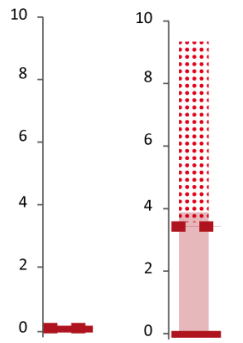

Figure 7. Frequency of years (out of 10) with monthly influenced streamflow inferior to the objective monthly environmental flow $Q_{\mathrm{OBJ}}$ in (a) the Herault basin and (b) the Ebro basin. Frequencies are considered acceptable under 2 years out of 10.

\subsection{Anthropogenic pressure on water resources}

In the Herault basin simulated anthropogenic pressure on water resources remains low at an annual time step: it increases from 2 to $3 \%$ between the current water use and the trend water use scenario, and it reaches 2 to $3 \%$ under climate change scenarios and 3 to $4 \%$ under a combination of water use trend and climate scenarios. In the combination of current water uses and reference climate, anthropogenic pressures on water resources at the outlet of the Herault basin reach $20 \%$ of natural streamflow at the end of July (Fig. 6a). Anthropogenic pressure increases and reaches $27 \%$ of natural streamflow at the same period under the water use trend scenario. Under climate change scenarios, consumptive use is projected to increase slightly earlier in the year, with an earlier and more marked peak than in the reference climate. This peak reaches 25 to $45 \%$ (depending on the climate change scenario) with climate change only, and 30 to $50 \%$ with the water use trend scenario under climate change.

Figure $6 \mathrm{~b}$ shows the high impact of storage on streamflow in the Ebro basin: the anthropogenic impact is the highest in spring and fall, and decreases in summer when water withdrawals are at their highest. This can be due to with- drawals being made mostly in the reservoirs, and to the operation of the Mequinenza, Ribaroja and Flix dams, which aims to secure a flow of $100 \mathrm{~m}^{3} \mathrm{~s}^{-1}$ for the Ebro delta. This environmental flow constraint also explains the decrease of anthropogenic impact under climate change scenarios: although natural streamflow decreases in the climate change scenarios, the outflow from the dams was kept at a minimum of $100 \mathrm{~m}^{3} \mathrm{~s}^{-1}$, thus leaving a larger percentage of natural flow at the outlet. Anthropogenic pressure on water resources reaches $38 \%$ of annual flow under current conditions and increases to $45 \%$ of annual natural streamflow under the water use trend scenario. Climate change scenarios result in an increase in anthropogenic pressure, ranging from 36 to $44 \%$ with current water uses and from 43 to $52 \%$ when combined with the water use trend scenario.

Figure 7 shows the results of the comparison of simulated influenced streamflow with environmental flows $Q_{\mathrm{OBJ}}$ at a monthly time step. Monthly environmental flows $Q_{\text {OBJ }}$ are reached more than 8 years out of 10 in all sub-basins of the Herault and Ebro basins, under current water uses and reference climate variability. However, the water use trend scenario causes an increase in the frequency of unsatisfactory 
years (when influenced streamflow is inferior to environmental objectives) at the outlet of the Ebro basin. Conversely, it improves the respect of environmental flows in the Gignac (Fig. 7a) and Bardenas (Fig. 7b) areas. Climate change scenarios lead to a non-compliance with monthly environmental flows in the Lodève, Saint-Laurent and Gignac areas of the Herault basin and in all areas except the Cinca and the Segre sub-basins in the Ebro basin. Finally, the combination of the trend water use scenario and climate change scenarios is projected to have a high impact on the compliance with environmental flows in the Ebro at Tortosa.

\section{Discussion and conclusion}

\subsection{Significance for water management}

The purpose of this study was to assess the sustainability of planned water uses under an ensemble of climate change scenarios using a conceptual modeling framework, and to determine the possible causes of unsustainability. The sustainability of water uses was appraised through the risk of imbalance between water availability and demand over the long term (several decades), i.e., the possibility to satisfy demands for human water use while keeping withdrawals and consumptive use at environmentally sustainable levels. The sustainability of planned water uses was assessed by simulating water demand satisfaction and the pressures of water uses on resources considering climate variability over 30-year periods, in water use and climate scenarios. Results showed that objective monthly environmental flows would be guaranteed in current climate conditions in both basins. Yet in several areas this could imply limiting human water uses more than once every 5 years, which implies a need to adapt water uses to lower water availability, or "doing better with what we have" as suggested by Molle et al. (2010). Moreover, the impact of the tested climate projections on both water availability and demand could question the water allocations and environmental constraints currently planned for the coming decades. Indeed, under climate change and water use scenarios, water shortages for human use could become more frequent and intense, and the pressure on water resources and aquatic ecosystems could intensify.

In some areas the plans to increase water use, rather than the decrease in availability under climate change scenarios, should cause an imbalance between water use and availability: in four areas of the Ebro basin (Alto Aragon, Aragon and Catalunya, Segre and lower Ebro), current water uses could be sustainable under climate change scenarios. In these areas if water uses change according to local plans, water demands should be satisfied in current climate conditions. Yet a risk of water stress could appear over a longer term, under a changing climate. However note that it may be harder by then to reduce, than to curb its increase from now on. In other areas water stress should be induced mainly by climate change, no- tably in the Herault basin. Our results showed that the fixed environmental flows could frequently be unsatisfied, even with frequent limitations of water withdrawals. Facing decreasing natural low flows, the question arises whether regulatory minimum flows can be kept at their current level. Then again, increased consumptive use as shown by simulations under climate change scenarios could further impact ecosystems already perturbed by warmer temperatures, lower flows and quickly changing conditions.

The comparison of the Herault and Ebro basins shows that the regulated systems on the left bank of the Ebro could be only slightly impacted by climate change, up to a certain level in agricultural water demand, whereas systems with limited streamflow regulation such as the Herault basin should be directly affected by any decrease in summer low flows. Although anthropogenic pressures on resources were shown to be much higher in the Ebro than in the Herault basin, some of the main water uses could remain in balance with water availability. However, in the Ebro basin only the large, regulated demand nodes were studied; water stress within each area may be quite heterogeneous, in the same way as the different areas of the Herault basin. Nevertheless, both scales of study remain pertinent, since they each match a scale of water management and planning.

In most areas, results were highly dependent on the climate change scenario. Although this may induce some difficulties in the analysis of results, the breadth of uncertainty in future climates must be considered, and characterizing the range of possible climate change scenarios is essential to limit the risk of over-reliance on one uncertain projection and thus the risk of maladaptation (Pielke, 2001; Wilby, 2010). Also, the sensitivity to climate uncertainties was shown to vary between the demand nodes. For example in the Herault basin, the areas of Laroque, Saint-Laurent and Lodève, which have comparable frequencies of water shortage in reference conditions, exhibited different sensitivities to climate uncertainties (see Fig. 5).

\subsection{Contributions of the integrated modeling framework}

The integrated modeling framework enabled us to account for many interactions within the two studied hydrosystems. Upstream-downstream interactions were considered through the simulation of water withdrawals, return flows and consumptive use. Interactions between water uses were also accounted for: water demand in the Ebro is mostly agricultural and thus water shortages are mostly caused by a hydroclimatic deficit, whereas in the Herault basin agricultural water withdrawals can be limited because of the priority given to UWD. In this way the increase in irrigation efficiency in the Gignac area should not lead to an improvement of AWD satisfaction if it occurs concurrently with the increase in UWD of the Agde area, as suggested in the trend water use scenario. Finally, by differentiating the impacts of climate change from 
those of socioeconomic and demographic trends, the modeling framework helped assess the cause of the hydrosystems' vulnerability to water stress, which, as underlined by Blöschl and Montanari (2010), is an essential value of climate change impact studies. The identification of the drivers of water stress in basins facing rapid climatic and anthropogenic changes is also at the heart of the challenges put forward in the Panta Rhei hydrological scientific decade of the IAHS (International Association of Hydrological Sciences) (Montanari et al., 2014).

The indicators used in this study to characterize the balance between availability and demand were sensitive to the dynamics of anthropogenic pressures, and should help anticipate undesirable situations, as recommended by Juwana et al. (2012). They enabled us to assess the frequency and magnitude of deficits, and thus helped to qualify the vulnerability of the studied hydrosystems to water stress. The impacts of future changes will indeed be different in areas experiencing more frequent years of shortage of the same magnitudes (see the upstream areas of the Herault basin), than in areas exposed to increased annual deficits (such as the Gignac and Agde areas of the Herault basin or the Alto Aragon area of the Ebro basin) or to shortage events with an increased deficit (such as the Gignac area).

\subsection{Limitations and uncertainties}

Although efforts were made to account for uncertainty in future water stress by using a wide range of climate scenarios, the full range of uncertainties was far from being completely covered in this study. Different downscaling techniques, hydrological models (e.g., Jiang et al., 2007; Jones et al., 2006) or water use scenarios (e.g., Purkey et al., 2008; Reynard et al., 2014; Shamir et al., 2015) could be used, for example, to cover a wider range of uncertainty. Note that only one water use scenario was compared to many climate change scenarios. However, the trend water use scenario should be seen here not as a projection for water managers of what water uses could be at the 2050 horizon, but rather as a quantification (with the expected modeling uncertainties) of water demand associated with the demographic and socioeconomic trends that local managers included in their planning documents for the mid-term. Thus, the trend water use scenario should be considered as a reference state on which to base the design of adaptation measures.

This prospective study was based on debatable assumptions regarding the stationarity of hydrological processes and of water management, which may be seen as partly unrealistic. Notably, keeping the parameters of the hydrological model obtained by calibration over 1981-2009 in all simulations raises the question of hydrological non-stationarity. The robustness of conceptual hydrological models under changing climatic and anthropogenic drivers is an essential question for impact studies. According to published research, it seems in the range of climate change studied here, hydrolog- ical model parameters could be transposable (Coron et al., 2012; Vaze et al., 2010). Moreover, climate projections at the 2050 horizon only accounted for mean monthly changes, due to the downscaling method. Also, note that the water use scenarios were built with constant anthropogenic drivers over 30 years, while simulations over the past 40 years (Fabre et al., 2015a) showed that the non-stationarity of anthropogenic forcings was a key element to be considered in hydrological modeling. However, one could argue that since the sequence of wet and dry years from the reference period was kept in climate projections, it might not make more sense to consider varying population and irrigated areas, considering that the climate variability over the 30 -year period is unpredictable. Thus, to account for the variability of anthropogenic pressures in future scenarios, it would seem more pertinent to use a large range of stationary water use scenarios and to confront them to different climate scenarios over multi-decadal periods.

Finally, some authors have questioned the use of indicators to assess and predict water stress (e.g., Molle and Mollinga, 2003), arguing that indicators tend to aggregate reality and even out spatial and temporal heterogeneities. Although the authors concede that indicators calculated at a local level and resulting from a complete study may give accurate information, they argue that the added value of using indicators is unclear. In the present study we used indicators to facilitate the comparison of different scenarios: rather than the absolute values of the indicators in each scenario, it is the changes in their values between different scenarios that counts the most. Nevertheless, the question remains of the use of these indicators to represent the vulnerability of hydrosystems to water stress. The indicators used in this paper could in fact be considered as harm indicators, quantifying changes in the frequency and magnitude of water shortage for human use. They do not completely grasp the notion of vulnerability, which, according to Hinkel, cannot be measured. Complementary studies using a bottom-up approach, focusing on social vulnerability and adaptive capacity (e.g., Bhave et al., 2014; Burton et al., 2002; Farley et al., 2011; Wilby and Dessai, 2010) would be needed to assess the vulnerability of these two river basins to water stress. Indeed different systems may not react in the same way to similar water shortage frequency of intensities. In the Laroque area of the Herault basin, for example, summer low flows are sensitive to climatic variability, with no storage capacity to lessen the pressure of summer withdrawals. Furthermore, aquatic ecosystems in this area are fragile and of high value; therefore, environmental flows are of particular interest. However, the local agriculture and thus economic activity is highly dependent on irrigation, and frequent limitations of water withdrawals may question this activity. 


\subsection{Prospects}

Applying this integrated modeling framework in different combinations of climate and water use scenarios helped to answer the question of the sustainability of water uses under climate- and human-induced changes, and to determine the causes of water shortage risks. This study enables us to approach possible adaptation options to improve the sustainability of water uses for each study area. In the Herault basin, water managers will have to address the satisfaction of UWD, while accounting for interactions between water uses and between upstream and downstream. For instance this study showed that the efforts regarding irrigation efficiency in Gignac would not necessarily induce an increase in the satisfaction of local agricultural demand because of the priority given to the satisfaction of urban water demand further downstream. In the Ebro adaptation will most likely relate to agricultural water demand. Modifying dam management could have an impact on the balance between demand and availability; however, caution is needed while considering long-term investments, which may not be effective over the long term in non-stationary climate conditions (Hallegatte, 2009). This was well illustrated in this study by the case of the Yesa dam in the Bardenas area of the Ebro basin, where the benefits of the dam enlargement could be partly offset by climate change.

The next step of this work, currently underway, is thus to assess the sensitivity of future changes in water demand satisfaction to variations in the water use scenarios, and to propose scenarios of sustainable changes in water uses, both effective in reducing the gap between water demand and availability, and robust to climate uncertainties.

Acknowledgements. This work was carried out as part of the GICC REMedHE project funded by the French Ministry of Ecology, Sustainable Development and Energy for the period 2012-2015. The authors thank the Syndicat Mixte du Bassin du Fleuve Hérault and the Confederación Hidrográfica del Ebro for providing the necessary data and documents for this study. Climatic data for the Ebro basin was provided by the Agencia Estatal de Meteorología (AEMET). We acknowledge the World Climate Research Programme's Working Group on Coupled Modeling, which is responsible for CMIP, and we thank the climate modeling groups (listed in Table 1 of this paper) for producing and making available their model output. For CMIP the US Department of Energy's Program for Climate Model Diagnosis and Intercomparison provides coordinating support and led development of software infrastructure in partnership with the Global Organization for Earth System Science Portals.

Edited by: K. Stahl

Reviewed by: two anonymous referees

\section{References}

AERMC - Agence de l'eau Rhône Méditerranée Corse: Plan de bassin d'adaptation au changement climatique dans le domaine de l'eau, Bassin Rhône-Méditerranée, www.eaurmc.fr (last access: June 2015), 2014.

Allen, R., Pereira, L., Raes, D., and Smith, M.: Crop evapotranspiration - guidelines for computing crop water requirements, FAO Irrigation and drainage paper, 56 pp., 1998.

Arnell, N. and Lloyd-Hughes, B.: The global-scale impacts of climate change and agricultural water resources and flooding under new climate and socio-economic scenarios, Clim. Change, 122, 127-140, 2014.

Arnell, N., Livermore, M., Kovats, S., Levy, P., Nicholls, R., Parry, M., and Gaffin, S.: Climate and socio-economic scenarios for global-scale climate change impacts assessments: characterising the SRES storylines, Global Environ. Chang., 14, 3-20, 2004.

Beck, L. and Bernauer, T.: How will combined changes in water demand and climate affect water availability in the Zambezi river basin?, Global Environ. Chang., 21, 1061-1072, 2011.

Bhave, A., Mishra, A., and Raghuwanshi, N.: A combined bottomup and top-down approach for assessment of climate change adaptation options, J. Hydrol, 518, 150-161, 2014.

Bielsa, J. and Cazcarro, I.: Implementing Integrated Water Resources Management in the Ebro River Basin: From Theory to Facts, Sustainability, 7, 441-464, 2015.

Blöschl, G. and Montanari, A.: Climate change impacts - throwing the dice?, Hydrol. Process., 24, 374-381, 2010.

Burton, I., Huq, S., Lim, B., Pilifosova, O., and Schipper, E.: From impacts assessment to adaptation priorities: the shaping of adaptation policy, Clim. Policy, 2, 145-159, 2002.

Bär, R., Rouholahnejad, E., Rahman, K., Abbaspour, K., and Lehmann, A.: Climate change and agricultural water resources: A vulnerability assessment of the Black Sea catchment, Environ. Sci. Pol., 46, 57-69, 2015.

CHE - Confederación Hidrográfica del Ebro: Propuesta de Proyecto de Plan Hidrológico de la cuenca del Ebro. Memoria, www. chebro.es (last access: October 2014), 2013.

Collet, L., Ruelland, D., Borrell-Estupina, V., Dezetter, A., and Servat, E.: Integrated modeling to assess long-term water supply capacity of a meso-scale Mediterranean catchment, Sci. Total Environ., 461-462, 528-540, 2013.

Collet, L., Ruelland, D., Borrell-Estupina, V., and Servat, E.: Assessing the long-term impact of climatic variability and human activities on the water resources of a meso-scale Mediterranean catchment, Hydrol. Sci. J., 59, 1457-1469, 2014.

Collins, W. J., Bellouin, N., Doutriaux-Boucher, M., Gedney, N., Halloran, P., Hinton, T., Hughes, J., Jones, C. D., Joshi, M., Liddicoat, S., Martin, G., O’Connor, F., Rae, J., Senior, C., Sitch, S., Totterdell, I., Wiltshire, A., and Woodward, S.: Development and evaluation of an Earth-System model - HadGEM2, Geosci. Model Dev., 4, 1051-1075, doi:10.5194/gmd-4-10512011, 2011.

Cook, C. and Bakker, K.: Water security: Debating an emerging paradigm, Global Environ. Chang., 22, 94-102, 2012.

Coron, L., Andréassian, V., Perrin, C., Lerat, J., Vaze, J., Bourqui, M., and Hendrickx, F.: Crash testing hydrological models in contrasted climate conditions: an experiment on 216 Australian catchments, Water Resour. Res., 48, W05552, doi:10.1029/2011WR011721, 2012. 
Dessai, S. and Hulme, M.: Does climate adaptation policy need probabilities?, Clim. Policy, 4, 107-128, 2004.

Dessai, S. and Hulme, M.: Assessing the robustness of adaptation decisions to climate change uncertainties: a case study on water resources management in the East of England, Global Environ. Chang., 17, 59-72, 2007.

Dessai, S., Hulme, M., Lempert, R., and Pielke, R.: Climate prediction: a limit to adaptation?, Adapting to climate change: thresholds, values, governance, 64-78, 2009.

Dezetter, A., Fabre, J., Ruelland, D., and Servat, E.: Selecting an optimal climatic dataset for integrated modeling of the Ebro hydrosystem, in: Hydrology in a changing world: environmental and human dimensions (Proc. 7th FRIEND Int. Conf., Montpellier, France, 7-10 October 2014), 363, 355-360, IAHS Publ., 2014.

Donley, E., Naiman, R., and Marineau, M.: Strategic planning for instream flow restoration: a case study of potential climate change impacts in the central Columbia River basin, Glob. Change Biol., 18, 3071-3086, 2012.

Dufresne, J., Foujols, M., Denvil, S., Caubel, A., Marti, O., Aumont, O., Balkanski, Y., Bekki, S., Bellenger, H., Benshila, R., Bony, S., Bopp, L., Braconnot, P., Brockmann, P., Cadule, P., Cheruy, F., Codron, F., Cozic, A., Cugnet, D., de Noblet, N., Duvel, J., Ethé, C., Fairhead, L., Fichefet, T., Flavoni, S., Friedlingstein, P., Grandpeix, J., Guez, L., Guilyardi, E., Hauglustaine, D., Hourdin, F., Idelkadi, A., Ghattas, J., Joussaume, S., Kageyama, M., Krinner, G., Labetoulle, S., Lahellec, A., Lefebvre, M., Lefevre, F., Levy, C., Li, Z., Lloyd, J., Lott, F., Madec, G., Mancip, M., Marchand, M., Masson, S., Meurdesoif, Y., Mignot, J., Musat, I., Parouty, S., Polcher, J., Rio, C., Schulz, M., Swingedouw, D., Szopa, S., Talandier, C., Terray, P., Viovy, N., and Vuichard, N.: Climate change projections using the IPSL-CM5 Earth System Model: from CMIP3 to CMIP5, Clim. Dynam., 40, 2123-2165, 2013

Dunne, J., John, J., Adcroft, A., Griffies, S., Hallberg, R., Shevliakova, E., Stouffer, R., Cooke, W., Dunne, K., Harrison, M., Krasting, J., S.L. Malysheva, d. P. M., Phillipps, P., Sentman, L., Samuels, B., Spelman, M., Winton, M., Wittenberg, A., and Zadeh, N.: Gfdl's esm2 global coupled climate-carbon earth system models. part i: physical formulation and baseline simulation characteristics, J. Climate, 25, 6646-6665, 2012.

Déqué, M.: Frequency of precipitation and temperature extremes over France in an anthropogenic scenario: model results and statistical correction according to observed values., Global Planet Change, 57, 16-26, 2007.

Döll, P.: Impact or climate change and variability on irrigation requirements: a global perspective, Clim. Change, 54, 269-293, 2002

European Commission: Directive 2000/60/EC of the European Parliament and of the Council establishing a framework for the Community action in the field of water policy, 2000.

Fabre, J., Collet, L., Milano, M., Ruelland, D., Dezetter, A., ArdoinBardin, S., and Servat, E.: Assessing the long-term evolution of water supply capacity: comparison of two Mediterranean catchments, in: Hydrology in a changing world: environmental and human dimensions (Proc. 7th FRIEND Int. Conf., Montpellier, France, 7-10 Oct. 2014), 363, 203-208, IAHS Publ., 2014.

Fabre, J., Ruelland, D., Dezetter, A., and Grouillet, B.: Simulating past changes in the balance between water demand and avail- ability and assessing their main drivers at the river basin scale, Hydrol. Earth Syst. Sci., 19, 1263-1285, doi:10.5194/hess-191263-2015, 2015a.

Fabre, J., Ruelland, D., Dezetter, A., and Grouillet, B.: Accounting for hydro-climatic and water use variability in the assessment of past and future water balance at the basin scale, Proc. Int. Assoc. Hydrol. Sci., 371, 43-48, 2015 b.

Farley, K., Tague, C., and Grant, C.: Vulnerability of water supply from the Oregon Cascades to changing climate: Linking science to users and policy, Global Environ. Chang., 21, 110-122, 2011.

Fujihara, Y., Tanaka, K., Watanabe, T., Nagano, T., and Kojiri, T.: Assessing the impacts of climate change on the water resources of the Seyhan River Basin in Turkey: Use of dynamically downscaled data for hydrologic simulations, J. Hydrol., 353, 33-48, 2008.

García-Vera, M.: The application of hydrological planning as a climate change adaptation tool in the Ebro basin, Int. J. Water Resour. Develop., 29, 219-236, 2013.

Gleick, P.: The Changing Water Paradigm. A Look at Twenty-first Century Water Resources Development, Water Int., 25, 127-138, 2000.

Griffin, M., Montz, B., and Arrigo, J.: Evaluating climate change induced water stress: A case study of the Lower Cape Fear basin, NC, Appl. Geogr., 40, 115-128, 2013.

Grouillet, B., Fabre, J., Ruelland, D., and Dezetter, A.: Historical reconstruction and 2050 projections of water demand under anthropogenic and climate changes in two contrasted Mediterranean catchments, J. Hydrol., 522, 684-696, 2015.

GWP - Global Water Partnership: Towards Water Security: A Framework for Action, Tech. rep., Global Water Partnership, 2000.

Hallegatte, S.: Strategies to adapt to an uncertain climate change, Global Environ. Chang., 19, 240-247, 2009.

Hargreaves, G. and Samani, Z.: Reference crop evapotranspiration from temperature, Appl. Eng. Agric., 1, 96-99, 1985.

Heinrichs, T., Lehner, B., and Alcamo, J.: An Integrated Analysis of Change in Water Stress in Europe, Int. Assess., 3, 15-29, 2012.

Hinkel, J.: Indicators of vulnerability and adaptive capacity: towards a clarification of the science-policy interface, Global Environ. Chang., 21.

IPCC: Climate Change 2013: The Physical Science Basis. Contribution of Working Group I to the Fifth Assessment Report of the Intergovernmental Panel on Climate Change, 2013.

Jiang, T., Chen, Y., XU, C., Chen, X., and Singh, V.: Comparison of hydrological impacts of climate change simulated by six hydrological models in the Dongjiang Basin, South China, J. Hydrol., 336, 316-333, 2007.

Jones, R., Chiew, F., Boughton, W., and Zhang, L.: Estimating the sensitivity of mean annual runoff to climate change using selected hydrological models, Adv. Water Resour., 29, 1419-1429, 2006.

Juwana, I., Muttil, N., and Perera, B.: Indicator-based water sustainability assessment - A review, Sci. Tot. Env., 438, 357-371, 2012.

Kirby, J., Connor, J., Ahmad, M., Gao, L., and Mainuddin, M.: Climate change and environmental water reallocation in the MurrayDarling Basin: Impacts of flows, diversions and economic returns to irrigationa, J. Hydrol., 518, 120-129, 2014. 
Kundzewicz, Z. and Stakhiv, E.: Are climate models "ready for prime time" in water resources management applications, or is more research needed?, Hydrol. Sci. J., 55, 1085-1089, 2010.

Letcher, R., Croke, B., and Jakeman, A.: Integrated assessment modelling for water resource allocation and management: a generalized conceptual framework, Environ. Model. Softw., 22, 733-742, 2007.

Ludwig, F., van Slobbe, E., and Cofino, W.: Climate change adaptation and Integrated Water Resource Management in the water sector, J. Hydrol., 518, 235-242, 2014.

López-Moreno, J., Zabalza, J., Vicente-Serrano, S., Revuelto, J., Gilaberte, M., Azorin-Molina, C., Morán-Tejeda, E., García-Ruiz, J., and Tague, C.: Impact of climate and land use change on water availability and reservoir management: Scenarios in the Upper Aragón River, Spanish Pyrenees, Sci. Tot. Environ., 493, 12221231, 2014.

Martin, G. M., Bellouin, N., Collins, W., Culverwell, I., Halloran, P., Hardiman, S., Hinton, T., Jones, C., McDonald, R., McLaren, A., O'Connor, F., Roberts, M., Rodriguez, J., Woodward, S., Best, M., Brooks, M., Brown, A., Butchart, N., Dearden, C., Derbyshire, S., Dharssi, I., Doutriaux-Boucher, M., Edwards, J., Falloon, P., Gedney, N., Gray, L., Hewitt, H., Hobson, M., Huddleston, M., Hughes, J., Ineson, S., Ingram, W., James, P., Johns, T., Johnson, C., Jones, A., Jones, C., Joshi, M., Keen, A., Liddicoat, S., Lock, A., Maidens, A., Manners, J., Milton, S., Rae, J., Ridley, J., Sellar, A., Senior, C., Totterdell, I., Verhoef, A., Vidale, P., and Wiltshire, A.: The HadGEM2 family of Met Office Unified Model climate configurations, Geosci. Model Dev., 4, 723-757, doi:10.5194/gmd-4-723-2011, 2011.

Menzel, L. and Matovelle, A.: Current state and future development of blue water availability and blue water demand: A view at seven case studies, J. Hydrol., 384, 245-263, 2010.

Milano, M., Ruelland, D., Dezetter, A., Fabre, J., Ardoin-Bardin, S., and Servat, E.: Modeling the current and future capacity of water resources to meet water demands in the Ebro basin, J. Hydrol., 500, 114-126, 2013a.

Milano, M., Ruelland, D., Fernandez, S., Dezetter, A., Fabre, J., Servat, E., Fritsch, J.-M., Ardoin-Bardin, S., and Thivet, G.: Current state of Mediterranean water resources and future trends under climatic and anthropogenic changes, Hydrol. Sci. J., 58, 498518, 2013b.

Milly, P., Betancourt, J., Falkenmark, M., Hirsch, R., Kundzewicz, Z., and Lettenmaier, D.: Stationarity is dead: Whither water management?, Science, 319, 573-574, 2008.

Molle, F. and Mollinga, P.: Water poverty indicators: conceptual problems and policy issues, Water Pol., 5, 529-544, 2003.

Molle, F., Wester, P., and Hirsch, P.: River basin closure: Processes, implications and responses, Agr. Water Manage., 97, 569-577, 2010.

Montanari, A., Young, G., Savenije, H., Hughes, D., Wagener, T., Ren, L., Koutsoyiannis, D., Cudennec, C., Toth, E., Grimaldi, S., Blöschl, G., Sivalapan, M., Beven, K., Gupta, H., Hipsey, M., Schaefli, B., Arheimer, B., Boegh, E., Schymanski, S., Baldassarre, G. D., Yu, B., Hubert, P., Huang, Y., Schumann, A., Post, D., Srinivasan, V., Harman, C., Thompson, S., Rogger, M., Viglione, A., McMillan, H., Characklis, G., Pang, Z., and Belyaev, V.: 'Panta Rhei - Evrything Flows': Change in hydrology and society - The IAHS Scientific Decade 2013-2022, Hydrolog. Sci. J., 58, 1256-1275, 2014.
Nam, W., Choi, J., and Hong, E.: Irrigation vulnerability assessment on agricultural water supply risk for adaptive management of climate change in South Korea, Agr. Water Manage., 152, 173-187, 2015.

Nkomozepi, T. and Chung, S.: The effects of climate change on the water resources of the Geumho River Basin, Republic of Korea, J. Hydro-Environ. Res., 8, 358-366, 2014.

Palazzoli, I., Maskey, S., Uhlenbrook, S., Nana, E., and Bocchiola, D.: Impact of prospective climate change on water resources and crop yields in the Indrawati basin, Nepal, Agr. Syst., 133, 143157, 2015.

Patt, A., Klein, R., and de la Vega-Leinert, A.: Taking the uncertainty in climate change vulnerability assessments seriously, C. R. Geosci., 337, 411-424, 2005.

Perrin, C., Michel, C., and Andreassian, V.: Improvement of a parsimonious model for streamflow simulation, J. Hydrol., 10, 282 290, 2003.

Pielke, R.: Collateral damage from the death of stationarity, GEWEX Newsletter, May 2009, 5-7, 2009.

Pielke, R. J.: Room for doubt, Nature, 410, 151-151, 2001.

Pulido-Velazquez, D., Garrote, L., Andreu, J., Martin-Carrasco, F.J., and Iglesias, A.: A methodology to diagnose the effect of climate change and to identify adaptive strategies to reduce its impacts in conjunctive-use systems at basin scale, J. Hydrol., 405, 110-122, 2011.

Purkey, D., Joyce, B., Vicuna, S., Hanemann, M., Dale, L., Yates, D., and Dracup, A.: Robust analysis of future climate change impacts on water for agriculture and other sectors: a case study in the Sacramento Valley, Clim. Change, 87, 109-122, 2008.

Reynard, E., Bonriposi, M., Graefe, O., Homewood, C., Huss, M., Kauzlaric, M., Liniger, H., Rey, E., Rist, S., Schädler, B., Schneider, F., and Weingartner, R.: Interdisciplinary assessment of complex regional water systems and their future evolution: how socioeconomic drivers can matter more than climatee, WIREs Water, 1, 413-426, 2014.

Rinaudo, J.: Urbanisme, habitat et demande en eau potable Scénarios 2030 pour le Pays Coeur d'Hérault., Tech. Rep. BRGM/RP-60368-FR, BRGM, 2011.

Rotstayn, L. D., Jeffrey, S. J., Collier, M. A., Dravitzki, S. M., Hirst, A. C., Syktus, J. I., and Wong, K. K.: Aerosol- and greenhouse gas-induced changes in summer rainfall and circulation in the Australasian region: a study using single-forcing climate simulations, Atmos. Chem. Phys., 12, 6377-6404, doi:10.5194/acp-126377-2012, 2012.

Ruelland, D., Ardoin-Bardin, S., Collet, L., and Roucou, P.: Simulating future trends in hydrological regime of a large SudanoSahelian catchment under climate change, J. Hydrol., 424-425, 207-216, 2012.

Räisänen, J.: How reliable are climate models?, Tellus, 59A, 2-29, 2007.

Schwank, J., Escobar, R., Girón, G., and Morán-Tejeda, E.: Modeling of the Mendoza river watershed as a tool to study climate change impacts of water availability, Environ. Sci. Pol., 43, 9197, 2014.

Shamir, E., Megdal, S., Carillo, C., Castro, C., Chang, H., Chief, K., Corkhill, F., Eden, S., Georgakakos, K., Nelson, K., and Prietto, J.: Climate change and water resources management in the Upper Santa Cruz River, Arizona, J. Hydrol., 521, 18-33, 2015. 
SMBFH - Syndicat Mixte du Bassin du Fleuve Hérault: Gestion quantitative de la ressource. Etat des lieux version 4. SAGE du bassin du fleuve Hérault, www.sage.herault.fr (last access: August 2014), 2005.

Smit, B. and Wandel, J.: Adaptation, adaptive capacity and vulnerability, Global Environ. Change, 156, 282-292, 2006.

Stevens, B., Giorgetta, M., Esch, M., Mauritsen, T., Crueger, T., Rast, S., Salzmann, M., Schmidt, H., Bader, J., Block, K., Brokopf, R., Fast, I., Kinne, S., Kornblueh, L., Lohmann, U., Pincus, R., Reichler, T., and Roeckner, E.: Atmospheric component of the MPI-M Earth System Model: ECHAM6, J. Adv. Model. Earth. Syst., 5, 146-172, 2013.

Vargas-Amelin, E. and Pindado, P.: The challenge of climate change in Spain: Water resources, agriculture and land, J. Hydrol., 518, 243-249, 2014.

Vaze, J., Post, D., Chiew, F., Perraud, J., Viney, N., and Teng, J.: Climate non-stationarity - Validity of calibrated rainfall-runoff models for use in climate change studies, J. Hydrol., 394, 447457, 2010

Vidal, J., Martin, E., Franchisteguy, L., Baillon, M., and Soubeyroux, J.: A 50-year high-resolution atmospheric reanalysis over France with the SAFRAN system, Int J. Climatol., 30, 16271644, 2010.

Voldoire, A., Sanchez-Gomez, E., Salas y Mélia, D., Decharme, B., Cassou, C., Sénési, S., Valcke, S., Beau, I., Alias, A., Chevallier, M., Déqué, M., Deshayes, J., Douville, H., Fernandez, E., Madec, G., Maisonnave, E., Moine, M.-P., Planton, S., SaintMartin, D., Szopa, S., Tyteca, S., Alkama, R., Belamari, S., Braun, A., Coquart, L., and Chauvin, F.: The CNRM-CM5.1 global climate model: description and basic evaluation, Clim. Dynam., 40, 2091-2121, 2013. von Salzen, K., Scinocca, J. F., McFarlane, N. A., Li, J., Cole, J. N. S., Plummer, D., Verseghy, D., Reader, M. C., Ma, X., Lazare, M., and Solheim, L.: The Canadian Fourth Generation Atmospheric Global Climate Model (CanAM4). Part I: Representation of Physical Processes, Atmos. Ocean, 51, 104-125, 2013.

Vörösmarty, C., Green, P., Salisbury, J., and Lammers, R.: Global water resources: vulnerability from climate change and population growth, Science, 289, 284-288, 2000.

Vörösmarty, C., McIntyre, P., Gessner, M., Dudgeon, D., Green, P., Glidden, S., Bunn, S., Sullican, C., Liermann, C. R., and Davies, P.: Global threats to human water security and river biodiversity, Nature, 467, 555-561, 2012.

Wanders, N. and Wada, Y.: Human and climate impacts on the $21 \mathrm{st}$ century hydrological drought, J. Hydrol., 526, 208-220, 2015.

Watanabe, M., Suzuki, T., O'ishi, R., Komuro, Y., Watanabe, S., Emori, S., Takemura, T., Chikira, M., Ogura, T., Sekiguchi, M., Takata, K., Yamazaki, D., Yokohata, T., Nozawa, T., Hasumi, H., Tatebe, H., and Kimoto, M.: Improved Climate Simulation by MIROC5: Mean States, Variability, and Climate Sensitivity, J. Climate, 23, 6312-6335, 2010.

Wilby, R.: Evaluating climate model outputs for hydrological applications, Hydrol. Sci. J., 55, 1090-1093, 2010.

Wilby, R. and Dessai, S.: Robust adaptation to climate change, Weather, 65, 180-185, 2010.

Wilby, R. and Harris, I.: A framework for assessing uncertainties in climate change impacts: low-flow scenarios for the River Thames, U.K., Water Resour. Res., 42, W02419, doi:10.1029/2005WR004065, 2006.

Woznicki, S., Nejadhashemi, A., and Parsinejad, M.: Climate change and irrigation demand: Uncertainty and adaptation, J. Hydrol., 3, 247-264, 2015. 